Accepted version

2 August 2018

\title{
Socioeconomic transition and its influence on Body Mass Index (BMI) pattern in Bangladesh
}

Raaj Kishore Biswas (corresponding), MS, Transport and Road Safety Research, University of New South Wales

Address: Old Main Building (K15) - Floor 1, Sydney, NSW 2052, Australia Telephone: +61 426784344 .

Fax: N/A

Email: RaajKishore.Biswas@student.unsw.edu.au

Enamul Kabir, $\mathrm{PhD}$

School of Agricultural, Computational and Environmental Sciences, University of Southern Queensland

Email: Enamul.Kabir@usq.edu.au

Hafiz T.A. Khan, $\mathrm{PhD}$

The Graduate School, University of West London, UK

Email: hafiz.khan@uwl.ac.uk 


\section{Socioeconomic transition and its influence on Body Mass Index (BMI) pattern in Bangladesh}

\section{Abstract}

\section{Rationale, aims, and objectives}

Bangladesh is an underdeveloped country that has recently joined the ranks of low-middle income countries. This study aims to investigate how socioeconomic and developmental factors have influenced women towards a shift in their Body Mass Index (BMI).

\section{Method}

The trend was analyzed using data on ever-married women from six nationwide surveys covering the years 1996 to 2014, conducted by the Bangladesh Demographic and Health Survey (BDHS). To assess the relationship between the socio-economic factors and BMI, binary regression models were fitted for six surveys and forest plots were applied to display the results.

\section{Results}

Factors such as age, education, residence, economic status and contraceptive use were found to have had an increasing influence on BMI over the years that were being analyzed. Age and education for women were potential factors influencing BMI. Growing urbanization and economic inequality were found to have been substantial over time and marital status and contraceptive use were influential whilst the employment status of women held no consequence.

\section{Conclusions}

Rapid urbanization allied with growing wealth inequality and dietary alteration seems to have forced a change in the capacity of women in Bangladesh to control their weight. Additional information is still needed on such factors as the amount of time that women are inactive and sitting down, for example, as well as their daily calorie intake in order to assemble all the pieces for addressing necessary health policy changes in Bangladesh. These factors will also help to indicate a shift of focus from rural malnutrition to urban obesity.

Keywords: $\quad$ BMI, Public health, Health policy, Trend analysis, Social trend 


\section{Introduction}

Bangladesh has recently been classed as a low-middle income country after previously being classed as underdeveloped. The change in classification creates the scope for channeling a first world problem into Bangladesh, that is, a problem of its people being overweight and/or obese alongside already existing malnutrition particularly in rural areas. A number of studies have focused on malnutrition in Bangladesh, $(1 ; 2 ; 3 ; 4 ; 5 ; 6 ; 7 ; 8)$; however assessments of the extent of people who are overweight or obese are still inconclusive. Prevalence of obesity is increasing all around the globe and has consequently become a risk factor for developing many serious illnesses $(9 ; 10 ; 11 ; 12)$. This study considered both underweight and overweight factors based on BMI as an unhealthy factor and assessed its association with various socio-economic issues. This broad dichotomization was considered due to insufficient nationwide data covering Bangladesh. The clinical association between BMI and malnutrition was not sufficient to separate malnutrition and obesity based only on BMI, so we settled for a broad binary outcome variable (health and unhealthy) $(13 ; 14 ; 15 ; 16)$. This study paves the way for a more focused study, preferably with primary data, that will focus on factors such as age, education, residence, economic status and contraceptive use that we found to be important in the context of Bangladesh and further scrutinized the trend for problems present in the developed world that are starting to surface in Bangladesh.

The most commonly applied measurement index for health and fitness is the Body Mass Index (BMI). Unfortunately, BMI levels vary over a number of factors: racial groups, ethnicity, geographic location, gender, age, hormone levels, and other socioeconomic influences (17; 18; 19). However, due to the lack of a standard BMI scale for Bangladesh, this study applied the typical BMI scaling for measuring the healthy $\left(18.5 \mathrm{~kg} / \mathrm{m}^{2}-24.9 \mathrm{~kg} / \mathrm{m}^{2}\right)$ and the unhealthy. This study also analyzed socioeconomic data to identify trends affecting the BMI of ever-married women covering the years 1996 to 2014. The data was extracted from six nationwide surveys conducted by the Bangladesh Demographic and Health Survey (BDHS) and then analyzed to determine the trend over these years and thereby helping to narrow the factors that could affect BMI. Rapid urbanization, high wealth inequality and dietary changes are potential culprits behind the trend. Thus, research in future can focus on specific socio-economic factors present in Bangladesh that can then help in reassessing 
existing health policy and determine with more certainty if there are plausible reasons for a shift from rural malnutrition to urban obesity.

An individual's weight and height ratio - BMI $\left(\mathrm{kg} / \mathrm{m}^{2}\right)$ - are associated with a range of diseases (20). Previous studies have shown the importance of controlling weight in accordance with individual body measure so as to help in leading a healthy disease-free life. Both low and high BMI give rise to higher risks of developing diseases $(21 ; 22 ; 23)$. Creating an individual parameter for proper weight maintenance is inevitably arbitrary; however, BMI is the best available measuring tool (24). The International Obesity Task Force provided a classification for BMI where healthy weight was considered to be in the range 18.5 to $24.9\left(\mathrm{~kg} / \mathrm{m}^{2}\right)$ (25), which is consistent with the decision of a steering committee of the American Institute of Nutrition (26) and an expert committee of the World Health Organization (27). This paper followed similar guidelines for determining healthy and unhealthy respondents in BDHS data sets. However, the accuracy and interpretations of BMI varies upon several factors like race, geographic locations, gender, ethnicity, and age $(28 ; 29 ; 30)$. The focus of the study is not concerned with the diagnostic performance of BMI. Due to the lack of a gold standard BMI range for ever-married women in Bangladesh, the generally accepted range of BMI was applied to segregate the healthy from the unhealthy.

Age and education are important socio-economic factors for controlling BMI. The average BMI has increased at an alarming rate for all ages but especially for adolescents in the USA and Australia $(31 ; 32 ; 33)$, where children and adults are subject to a high BMI (over $30 \mathrm{~kg} / \mathrm{m}^{2}$ ) and to chronic obesity $(34 ; 35)$. Another factor closely related to healthy lifestyles is education. The amount of education that individuals experience is associated with better self-reported health for both men and women (36). Education provides knowledge on side effects, regular medication use, and medication adherence (37). Furthermore, the education of primary caretakers, usually family members, is also important in helping to lead a healthy lifestyle (38). The effects of age and education should provide a trend for Bangladesh as they have also had an influence in other countries. 
A healthy lifestyle is also enhanced by area of residence, income status and employment. (39) showed that a difference in health was observed between two community types, urban and rural, that was explained by educational background, physical activity, and smoking with the urban residents more likely to be obese or overweight (40). The ability or capacity of individuals to access decent health care and nutrition is also important in maintaining a healthy disease-free life. The wealth gap in the USA has proven to be a strong factor in this, where the poorest Americans experience the greatest disadvantage (41). However, excess weight is more problematic for rich people in urban areas both in developed and developing nations (42). Interestingly, obesity also hampers the income of individuals and families by significantly reducing wealth status (43). A study in Korea that focused on the elderly population in that country found that unemployment was significantly related to obesity prevalence regardless of other socio-economic factors (44). This begs the question as to whether these factors are also influencing Bangladesh as it grows economically. Added to this, an increasing number of inhabitants from rural areas are moving to urban areas such as cities. The additional expansion of these urban areas is introducing dietary changes and a reduction in physical work available for residents which is potentially an important determinant in the BMI shift in Bangladesh $(45 ; 46)$.

For women, marriage has a high association with BMI where married women are found more likely to be overweight than compared to single women $(47 ; 48 ; 49)$. However, any assessment on the impact on BMI of a mothers age at the birth of her first child or number of ever-born children remains a challenge. One of the most researched topics in this area is the effect of contraception on the weight of women and their BMI. Despite some of the results being inconclusive, a relationship was detected with women's weight and a particular contraceptive method $(50 ; 51 ; 52)$. Although previous studies concentrated on a specific contraceptive method, it is worthwhile to detect the overall trend of traditional and modern methods of contraception on BMI.

\section{Methods}

BDHS (Bangladesh Demographic and Health Survey) in collaboration with DHS has been conducted in Bangladesh since 1993 (53). Measure DHS+ is a platform where data from developing countries on the demographic and health characteristics of populations are collected and analysed 
periodically every few years (54). Two-stage stratified cluster sampling techniques are applied for this survey and a list of enumeration areas (EAs) from the census is used as the sampling frame (53). Firstly, 600 EAs (or clusters) are selected using a proportional to size (PPS) sampling method. In the second stage, an equal probability systematic sampling method is applied to draw on an average of 30 households from each cluster. Strong literature exists on each survey conducted by BDHS (from 1993 to 2014) but accumulating all the surveys to try and identify any trends remains a challenge. The data comprised ever-married men aged 15 to 54 and ever-married women between 15 and 49. Only the women's samples were selected from the data sets with the sample numbers different for each survey. However, models were separately fitted for each survey in order to adjust the dissimilar sample sizes. The respondents with missing information were not included in the study sample. As explained in the Introduction, a broad binary outcome variable was used to assess the BMI pattern. The best possible method for analyzing such outcome is the binary regression model. In order to achieve a better fitting binary logistic regression model, available socio-economic factors were segregated into three categories and are displayed in Table 1.

[Table 1 here]

Table 1 displays the covariates used in the models. The scales of each model are defined in the BDHS data sets. However, the authors defined the age categories of the respondents and their partner's. Because the respondents were aged between 14 and 49, we dichotomized their age into: Young ( $\leq 25$ years) and Adult (over 25 years). However, the age of the partners was from 16 to above 80 . They were segregated into three categories: Young ( $<25$ years), adult ( $\geq 25$ and $\leq 59$ ) and old ( $>59$ years). We also collapsed the total number of children in the family equal or above 4 as ' $4+$ ' in the variable 'Total children ever born'.

The outcome variable is BMI, categorized into two scales: healthy $\left(18.5 \mathrm{~kg} / \mathrm{m}^{2}-24.9 \mathrm{~kg} / \mathrm{m}^{2}\right)$ and unhealthy $\left(<18.5 \mathrm{~kg} / \mathrm{m}^{2} \&>24.9 \mathrm{~kg} / \mathrm{m}^{2}\right)$. Bivariate analysis was conducted to provide an overview of the covariates. The significance of their association with the outcome variable (BMI) was determined by $p$-values from the Chi-square test (Table 2). Bivariate analysis evaluated the nature 
of association between the BMI outcome and other covariates of the six different surveys. However, bivariate association between two variables does not necessarily imply a significant causal relationship. For further understanding of the nature of their relationship and determining the significant effects, binary logistic regression model was fitted for BMI with variables in each category (Table 1) in three separate models. All computations were conducted in $R$ (version 3.2.3).

\section{Results}

\subsection{Bivariate Analysis}

The outcomes of the bivariate analysis from the six surveys are displayed in Table 2 to 4 . Most of the household characteristics showed significant association ( $p$ value $<0.001)$ with BMI.

\subsection{Binary Regression}

To assess the associations between the socio-economic factors and health status - BMI as well as their level of significance, binary regression models were fitted for all six surveys and forest plots were applied to display the results (Figure $1 \& 2$ ). Age groups of respondents and their partners in category I showed opposite results. From 1996 to 2016, women's ages indicated high influence over BMI, where the odds showed the younger generation of women were healthier than the older generation of women. Apart from the 2004 survey, a partners age did not show similar importance. In the case of levels of education attainment, both respondents and partners levels of literacy showed significance.

Women's education levels were significant (p-value < 0.05) in 2000, 2011 and 2014, whereas from 2000 all the surveys displayed the importance of a partner's education.

[Table 2 here]

[Table 3 here]

The area of residence of respondents became an important factor in maintaining weight after 2004, demonstrating the segregation between urban and rural areas in recent times. The difference in wealth has been a strong factor in wealth maintenance since 1996, which was gradually followed in every subsequent survey. However, the change in direction of the odds for 
the highest two quantiles are evident. Employment status, just like residence, became a significant phenomenon ( $\mathrm{p}$-value $<0.05)$ in later years.

Marital status and the number of total children ever born were important covariates influencing BMI score (Figure 2). However, the significant influence ( $p$-value $<0.05$ ) of the age of mothers at the birth of their first child was detected in recent times, specifically after the 2007 survey. Only modern contraceptive methods showed a positive impact on control of optimum weight levels, where the reference group was non-users.

[Table 4 here]

\subsection{Trend Analysis}

The odds ratios are displayed graphically through forest plots in Figure $1 \& 2$ to show the change in the effects of socio-economic factors on BMI over the years. The trends will determine the pathway of the influence of these factors as well as their type of effect (positive or negative). Odds one indicates an equilibrium state, which means there is no impact of that certain socioeconomic factor on BMI - that factor is no longer an important covariate in determining the maintenance of individual weight.

The gradual change in age is apparent in Figure 1(a). When compared with adults, young women were found to be more health conscious as the odds of maintaining a healthy BMI gradually declined in the years 2000 to 2014. Young women were less likely to have a higher BMI compared to adult women, indicated by the forest plot. The opposite result was attained from the ages of partners/husbands (Figure 1(b)). The odds of both young and adult groups increased reaching odds one, while the reference group of older partners showed that the age of partners had less impact on the BMI of women reaching equilibrium (odds one) over the years. The education of married women over 20 years has changed to positive odds ratios from negative ones. Educated women were more likely to be maintaining their weight levels before 2007 but then shifted in the opposite direction in later years (Figure $1(\mathrm{c})$ ). This shift was more evident in higher educated women compared to the uneducated, displayed in Figure 1(d). However, such a magnitude of 
change was not apparent in education of their partners (Figure 1(d, e). Interestingly, the highest educated married woman has never been able to maintain a healthy BMI in Bangladesh. The conclusion therefore is that a woman's age and education is currently more important than that of their partner/husband in Bangladesh.

Odds of the residences of respondents showed consistency over the years. The forest plot never favored urban residents (Figure 1(f)) meaning that a healthy BMI was more controlled in rural areas compared to urban areas in Bangladesh. Employment status, whether employed or not, showed inconsistent results with the odds ratios, moving around the equilibrium line indicating that work status did not have much effect in terms of maintaining a healthy BMI. However, the economic variation within society showed a clear trend for controlling weight (Figure $1(g, h)$ ). The lower and middle wealth quantile remained under the odds one line over the years showing no change in the last 20 years; the richer quantiles, especially the richest section, displayed tremendous changes as wealthy respondents failed to maintain a healthy weight in current times as compared to a few years ago. The tendency for wealthy urban residents to become overweight and obese is running concurrently with economic growth in Bangladesh.

The survey only targeted ever-married women and so single respondents were not included. The odds ratios of those widowed, divorced and living separately were compared in reference to married women (Figure 2(a, b)). After 2004, all the groups showed a decline in odds towards a healthy BMI. Women who were not living with their partners and were divorced were maintaining their weight more so than married women, whereas widows seemed unable to control their weight. Unlike marital status, all the scales of total children ever born showed consistency and reached equilibrium (odds one) from 1996 to 2014 (Figure 2(b, c)). Similar consistency was observed in the respondents age at first birth. The group aged 20 to 30 years had near constant odds over the years compared to the group of mothers under the age of 20 , showing that a healthy BMI was favoring women who gave birth under the age of 20. However, the group that became mothers at age 30 to 40 years showed equilibrium since 2004 ((Figure 2(d))). The effects of modern, traditional and folkloric contraceptive methods on BMI were compared in reference to non-users. The results showed two distinctive patterns: the respondents using modern methods 
had stronger control over their BMI and maintained their weight (Figure 1(a)), whereas the odds of traditional users remained slightly above the equilibrium (odds one) line so favoring the nonusers (Figure 2(e)). The sample size of the folkloric method users was too small to be conclusive.

[Figure 1here]

[Figure 2 here]

\section{Discussion}

The public health situation in Bangladesh has improved dramatically in recent years $(55 ; 56$; 57). However, that success features more prominently in the areas of sanitation and nutrition. This paper engages with the problems that Bangladesh will soon face as its economic growth continues specifically with overweight citizens and obesity $(58 ; 59 ; 60)$. With the gradual urbanization and fast food availability in Bangladesh increasing, weight control needs to receive more of a focus(61; 62). We approached this problem by analyzing trends in socio-economic factors in three categories that affect BMI, using data from six nationwide surveys conducted over the last 20 years. The results are displayed in Figure $1 \& 2$.

Older people in Bangladesh are failing to control their weight with the odds ratios showing that younger people are better at maintaining their weight levels. A weight increase alongside age is a

common phenomenon even for the most active individuals, but physical exercise is not very popular in Bangladesh, especially as part of a fitness regime which means that adults are getting caught in the trap of uncontrolled BMI (63). Additionally, the effect of stress in BMI is stronger for women and is higher for older individuals compared to the young and younger adults $(64 ; 65 ; 66)$. Occupational sitting time is high for educated individuals who prefer desk jobs that in turn increase the risk of being overweight or obese $(67 ; 68)$. These characteristics are considered to be problems in developed countries, and are emerging as trends in Bangladesh as well (69; 70). A woman in Bangladesh with a highly educated husband/partner seems unable to maintain their BMI. This could be an indication for the lack of a necessity to work and earn of women in rich families as well 
as the availability of domestic help, which release such women from manual labor also leading to weight gain $(71 ; 72)$.

The gradual effect of place of residence and wealth index over BMI can be explained by a change in dietary habits. With greater economic capacity and urbanization, a change in food habits is observed, particularly overconsumption of junk food that is more accessible to wealthier members of the population residing in metropolitan areas (73). Wealthy individuals have higher sitting times due to their occupations and the availability of such jobs in urban areas, making wealthy urban women fall victim to an unhealthy BMI (74).

From the results, Divorced or separated women looked to maintain better weight levels than married women. (75) showed that divorced women are more physically active and (76) also claimed that married adults have a higher prevalence of being overweight or obese. The odds ratio of the widowed compared to the married woman moved towards odds one in the latest survey. This suggests that married women are less concerned about their body weight compared to other marital influences. However, no change was found in the overall trend of the odds in the number of total children or a mothers age at childbirth. Contraceptive use showed an expected result where those using modern methods showed greater control of their BMI than traditional contraceptive users where the non-users were the reference category. Current literature accentuates these points (77). So young separated mothers and modern contraceptive users in Bangladesh tended to be fitter than their counterparts among ever-married women.

\section{Conclusions}

In search of trends for socio-economic factors influencing BMI in Bangladesh, this paper applied the BDHS from 1996 to 2014 and analyzed the odds ratios of the available socio-economic factors in order to aid understanding of their long-term relationship. The factors were categorized into three groups and were fitted with a binary regression model with BMI that was scaled into the healthy and the unhealthy. The big question to emerge from the findings in this study is, with the rate of its current economic growth, will Bangladesh have to start dealing with health problems more usually associated with the first world and is it ready to face such challenges? 
Over the years, the age and education of women in Bangladesh have become potential factors that influence BMI, whereas their partner's/husband's characteristics showed there was less of an impact. Growing urbanization and economic inequality are becoming more noteworthy as time progresses and, yet the employment status of women did not show any effect on BMI. Marital status and contraceptive use showed an expected consequence on BMI. All the socio-economic factors indicated that rapid urbanization coupled with wealth inequality and dietary changes is disrupting the weight control capacities of Bangladeshi women. A detailed data set of sitting time and specific calorie intake is required to assemble the rest of the pieces for addressing health policy changes in Bangladesh. Such data should then further indicate the shift of focus from malnutrition in rural areas to obesity in urban areas.

\section{Authors' contributions}

RK Biswas conceptualized the study, compiled the data, synthesized the analysis plan, interpreted the outcomes and drafted the manuscript. E Kabir aided the statistical analysis and helped to draft the manuscript. The manuscript was critically reviewed and edited by HTA Khan. All authors helped to write the manuscript and finalized the current version.

\section{Acknowledgements}

The authors would like to acknowledge Demographic and Health Survey (DHS), which conducted a nationwide survey and made their data available freely accessible. We thank the Faculty of Health, Engineering and Sciences (HES) of the University of Southern Queensland for the technical support it provided. We would also like to thank the anonymous reviewers and the academic editor for their inputs that improved the quality and clarity of the manuscript.

\section{Ethics approval}

This article does not contain any studies with human participants performed by any of the authors. The Bangladesh demographic and health Surveys were approved by ICF Macro 
Institutional Review Board and the National Research Ethics Committee of the Bangladesh Medical Research Council. A written consent about the survey was given by participants before interview. All identification of the respondents was dis-identified before publishing data. The secondary data sets analyzed during the current study are freely available upon request from the DHS website at http://dhsprogram.com/data/available-datasets.com.

\section{Funding}

This research received no specific grant from any funding agency in the public, commercial, or not-for-profit sectors.

\section{Conflict of Interest}

The authors declare that there is no conflict of interest regarding the publication of this paper.

\section{References}

1. Black, R.E., Brown, K.H., Becker, S.. Malnutrition is a determining factor in diarrheal duration, but not incidence, among young children in a longitudinal study in rural Bangladesh. The American journal of clinical nutrition $1984 ; 39(1): 87-94$.

2. Rayhan, M.I., Khan, M.S.H.. Factors causing malnutrition among under five children in Bangladesh. PakJ Nutr 2006;5(6):558-562.

3. Shafique, S., Akhter, N., Stallkamp, G., de Pee, S., Panagides, D., Bloem, M.W.. Trends of under-and overweight among rural and urban poor women indicate the double burden of malnutrition in Bangladesh. International Journal of Epidemiology 2007;36(2):449-457.

4. Thorne-Lyman, A.L., Valpiani, N., Sun, K., Semba, R.D., Klotz, C.L., Kraemer, K., Akhter, N., de Pee, S., MoenchPfanner, R., Sari, M., et al. Household dietary diversity and food expenditures are closely linked in rural Bangladesh, increasing the risk of malnutrition due to the financial crisis. The Journal of nutrition 2010;140(1):182S-188S.

5. Mondal, D., Minak, J., Alam, M., Liu, Y., Dai, J., Korpe, P., Liu, L., Haque, R., Petri, W.A.. Contribution of enteric infection, altered intestinal barrier function, and maternal malnutrition to infant malnutrition in Bangladesh. Clinical Infectious Diseases 2012;54(2):185-192.

6. Hossain, M., Bharati, P., Aik, S., Lestrel, P.E., Abeer, A., Kamarul, T.. Body mass index of married Bangladeshi women: trends and association with socio-demographic factors. Journal of biosocial science 2012;44(4):385-399. 
7. Kamal, S.M., Hassan, C.H., Alam, G.M.. Dual burden of underweight and overweight among women in Bangladesh: patterns, prevalence, and sociodemographic correlates. Journal of health, population, and nutrition 2015;33(1):92.

8. Islam, A., Islam, N., Bharati, P., Aik, S., Hossain, G.. Socio-economic and demographic factors influencing nutritional status among early childbearing young mothers in Bangladesh. BMC women's health 2016;16(1):58.

9. Wyatt, S.B., Winters, K.P., Dubbert, P.M.. Overweight and obesity: prevalence, consequences, and causes of a growing public health problem. The American journal of the medical sciences 2006;331(4):166-174.

10. Weller, R.E., Cook, E.W., Avsar, K.B., Cox, J.E.. Obese women show greater delay discounting than healthy weight women. Appetite 2008;51(3):563-569.

11. Basu, S., Vellakkal, S., Agrawal, S., Stuckler, D., Popkin, B., Ebrahim, S.. Averting obesity and type 2 diabetes in India through sugar-sweetened beverage taxation: an economic-epidemiologic modeling study. PLoS medicine 2014;11(1):e1001582.

12. Neuhouser, M.L., Aragaki, A.K., Prentice, R.L., Manson, J.E., Chlebowski, R., Carty, C.L., Ochs-Balcom, H.M., Thomson, C.A., Caan, B.J., Tinker, L.F., et al. Overweight, obesity, and postmenopausal invasive breast cancer risk: a secondary analysis of the women's health initiative randomized clinical trials. JAMA oncology 2015;1(5):611-621.

13. Stratton, R.J., Hackston, A., Longmore, D., Dixon, R., Price, S., Stroud, M., King, C., Elia, M.. Malnutrition in hospital outpatients and inpatients: prevalence, concurrent validity and ease of use of the malnutrition universal screening tool(must) for adults. British Journal of Nutrition 2004;92(05):799-808.

14. Duggan, M.. Anthropometry as a tool for measuring malnutrition: impact of the new who growth standards and reference. Annals of tropical paediatrics 2010;30(1):1-17.

15. White, J.V., Guenter, P., Jensen, G., Malone, A., Schofield, M., Group, A.M.W., Force, A.M.T., of Directors, A.B.. Consensus statement of the academy of nutrition and dietetics/american society for parenteral and enteral nutrition: characteristics recommended for the identification and documentation of adult malnutrition (undernutrition). Journal of the Academy of Nutrition and Dietetics 2012;112(5):730-738.

16. Tamura, B.K., Bell, C.L., Masaki, K.H., Amella, E.J.. Factors associated with weight loss, low bmi, and malnutrition among nursing home patients: a systematic review of the literature. Journal of the American Medical Directors Association 2013;14(9):649-655.

17. Gray, L.J., Yates, T., Davies, M.J., Brady, E., Webb, D.R., Sattar, N., Khunti, K.. Defining obesity cut-off points for migrant south asians. PLoS One 2011;6(10):e26464. 
18. Bahk, J.Y., Jung, J.H., Jin, L.M., Min, S.K.. Cut-off value of testes volume in young adults and correlation among testes volume, body mass index, hormonal level, and seminal profiles. Urology 2010;75(6):1318-1323.

19. Bahat, G., Tufan, F., Saka, B., Akin, S., Ozkaya, H., Yucel, N., Erten, N., Karan, M.A.. Which body mass index (bmi) is better in the elderly for functional status? Archives of gerontology and geriatrics 2012;54(1):78-81.

20. Stommel, M., Schoenborn, C.A.. Variations in bmi and prevalence of health risks in diverse racial and ethnic populations. Obesity 2010;18(9):1821-1826.

21. Field, A.E., Coakley, E.H., Must, A., Spadano, J.L., Laird, N., Dietz, W.H., Rimm, E., Colditz, G.A.. Impact of overweight on the risk of developing common chronic diseases during a 10-year period. Archives of internal medicine 2001;161(13):1581-1586.

22. WHO, E.C.. Appropriate body-mass index for Asian populations and its implications for policy and intervention strategies. Lancet (London, England) 2004;363(9403):157.

23. de Mutsert, R., Sun, Q., Willett, W.C., Hu, F.B., van Dam, R.M.. Overweight in early adulthood, adult weight change, and risk of type 2 diabetes, cardiovascular diseases, and certain cancers in men: a cohort study. American journal of epidemiology 2014;179(11):1353-1365.

24. Willett, W.C., Dietz, W.H., Colditz, G.A.. Guidelines for healthy weight. New England Journal of Medicine 1999;341(6):427-434.

25. Organization, W.H.. Obesity: preventing and managing the global epidemic. 894; World Health Organization; 2000.

26. Blackburn, G.L., Dwyer, J., Flanders, W., Hill, J., Kuller, L., Pi-Sunyer, F., St Jeor, S., Willett, W.. Report of the American institute of nutrition (ain) steering committee on healthy weight. J Nutr 1994;124(11):2240-3.

27. Organization, W.H., et al. Physical status: The use of and interpretation of anthropometry, report of a who expert committee 1995;.

28. Vikram, N.K., Pandey, R.M., Misra, A., Sharma, R., Devi, J.R., Khanna, N.. Non-obese (body mass indexi 25 kg/m 2) Asian Indians with normal waist circumference have high cardiovascular risk. Nutrition 2003;19(6):503- 509.

29. Romero-Corral, A., Somers, V.K., Sierra-Johnson, J., Thomas, R.J., Collazo-Clavell, M., Korinek, J., Allison, T.G., Batsis, J., Sert-Kuniyoshi, F., Lopez-Jimenez, F.. Accuracy of body mass index in diagnosing obesity in the adult general population. International journal of obesity 2008;32(6):959-966.

30. Lebel, A., Kestens, Y., Clary, C., Bisset, S., Subramanian, S.. Geographic variability in the association between socioeconomic status and bmi in the USA and Canada. PloS one 2014;9(6):e99158. 
31. Wang, Y., Beydoun, M.A.. The obesity epidemic in the united states gender, age, socioeconomic, racial/ethnic, and geographic characteristics: a systematic review and meta-regression analysis. Epidemiologic reviews 2007;29(1):6- 28.

32. Ogden, C.L., Carroll, M.D., Flegal, K.M.. High body mass index for age among us children and adolescents, 2003-2006. Jama 2008;299(20):2401-2405.

33. Kirton, J.W., Dotson, V.M.. The interactive effects of age, education, and bmi on cognitive functioning. Aging, Neuropsychology, and Cognition 2016;23(2):253-262.

34. Ogden, C.L., Carroll, M.D., Kit, B.K., Flegal, K.M.. Prevalence of obesity and trends in body mass index among us children and adolescents, 1999-2010. Jama 2012;307(5):483-490.

35. Flegal, K.M., Carroll, M.D., Kit, B.K., Ogden, C.L.. Prevalence of obesity and trends in the distribution of body mass index among us adults, 1999-2010. Jama 2012;307(5):491-497.

36. Arendt, J.N.. Does education cause better health? a panel data analysis using school reforms for identification. Economics of Education review 2005;24(2):149-160.

37. Hacihasano glu, R., G"ozu“m, S.. The effect of patient education and home monitoring on medication compliance, hypertension management, healthy lifestyle behaviours and bmi in a primary health care setting. Journal of clinical nursing 2011;20(5-6):692-705.

38. Torres, J.B., Solberg, V.S.. Role of self-efficacy, stress, social integration, and family support in latino college student persistence and health. Journal of vocational behavior 2001;59(1):53-63.

39. Fogelholm, M., Valve, R., Absetz, P., Heinonen, H., Uutela, A., Patja, K., Karisto, A., Konttinen, R., M"akel"a, T., Nissinen, A., et al. Ruralurban differences in health and health behaviour: a baseline description of a community health-promotion programme for the elderly. Scandinavian Journal of Public Health 2006;34(6):632- 640.

40. Mascie-Taylor, C.N., Goto, R.. Human variation and body mass index: a review of the universality of bmi cut-offs, gender and urban-rural differences, and secular changes. Journal of physiological anthropology 2007;26(2):109112.

41. Avendano, M., Glymour, M.M., Banks, J., Mackenbach, J.P.. Health disadvantage in us adults aged 50 to 74 years: a comparison of the health of rich and poor americans with that of europeans. American Journal of Public Health 2009;99(3):540-548.

42. Ziraba, A.K., Fotso, J.C., Ochako, R.. Overweight and obesity in urban africa: A problem of the rich or the poor? BMC public health 2009;9(1):1. 
43. Conley, D., Glauber, R.. Gender, body mass, and socioeconomic status: new evidence from the psid. Advances in health economics and health services research 2007;17:253-275.

44. Kang, H.T., Lee, H.R., Lee, Y.J., Linton, J.A., Shim, J.Y.. Relationship between employment status and obesity in a Korean elderly population, based on the 2007-2009 Korean national health and nutrition examination survey (knhanes). Archives of gerontology and geriatrics 2013;57(1):54-59.

45. Corsi, D.J., Kyu, H.H., Subramanian, S.. Socioeconomic and geographic patterning of under-and overnutrition among women in Bangladesh. The Journal of nutrition 2011;141(4):631-638.

46. Patil, P.S., Dixit, U.R., Hiralal, B.D.. Study of diabetes in dharwad-an urban area in India. Indian Journal of Science and Technology 2011;4(11):1481-1483.

47. Kahn, H.S., Williamson, D.F., Stevens, J.A.. Race and weight change in us women: the roles of socioeconomic and marital status. American Journal of Public Health 1991;81(3):319-323.

48. Lipowicz, A., Gronkiewicz, S., Malina, R.M.. Body mass index, overweight and obesity in married and never married men and women in Poland. American Journal of Human Biology 2002;14(4):468-475.

49. Malcolm, M., Kaya, I.. Selection works both ways: Bmi and marital formation among young women. Review of Economics of the Household 2016;14(2):293-311.

50. Pantoja, M., Medeiros, T., Baccarin, M.C., Morais, S.S., Bahamondes, L., dos Santos Fernandes, A.M.. Variations in body mass index of users of depot-medroxyprogesterone acetate as a contraceptive. Contraception 2010;81(2):107-111.

51. Gallo, M.F., Lopez, L.M., Grimes, D.A., Carayon, F., Schulz, K.F., Helmerhorst, F.M.. Combination contraceptives: effects on weight. The Cochrane Library 2014;.

52. Kapp, N., Abitbol, J.L., Math'e, H., Scherrer, B., Guillard, H., Gainer, E., Ulmann, A.. Effect of body weight and bmi on the efficacy of levonorgestrel emergency contraception. Contraception 2015;91(2):97-104.

53. DHS, . Bangladesh demographic and health survey 2014: National institute of population research and training (niport) 2016;

54. Rutstein, S.O., Johnson, K., MEASURE, O.M., et al. The DHS wealth index. ORC Macro, MEASURE DHS; 2004.

55. Chowdhury, A.M.R., Bhuiya, A., Chowdhury, M.E., Rasheed, S., Hussain, Z., Chen, L.C.. The Bangladesh paradox: exceptional health achievement despite economic poverty. The Lancet 2013;382(9906):1734-1745. 
56. Adams, A.M., Ahmed, T., El Arifeen, S., Evans, T.G., Huda, T., Reichenbach, L., et al. Innovation for universal health coverage in Bangladesh: a call to action. The Lancet 2013;382(9910):2104-2111.

57. Das, T.R.. Family planning program of Bangladesh: Achievements and challenges. South East Asia Journal of Public Health 2016;6(1):1-2.

58. Bhuiyan, M.U., Zaman, S., Ahmed, T.. Risk factors associated with overweight and obesity among urban school children and adolescents in Bangladesh: a case-control study. BMC pediatrics 2013;13(1):1.

59. Bulbul, T., Hoque, M.. Prevalence of childhood obesity and overweight in Bangladesh: findings from a countrywide epidemiological study. BMC pediatrics 2014;14(1):86.

60. Sarma, H., Saquib, N., Hasan, M.M., Saquib, J., Rahman, A.S., Khan, J.R., Uddin, M.J., Cullen, M.R., Ahmed, T.. Determinants of overweight or obesity among ever-married adult women in Bangladesh. BMC obesity 2016;3(1):13.

61. Karmakar, P., Jahan, N., Banik, S., Das, A., Rahman, K., et al. Food habits, obesity and nutritional knowledge among the university students in noakhali region of Bangladesh: A cross sectional study. J Food Nutr Disor 5: 4 doi: http://dx doi org/104172/2324 2016;9323:2.

62. Pervin, S., Wang, M., Mamun, A., Naheed, A.. Healthy eating and active living (heal): Feasibility and acceptability of implementing school-based intervention to control childhood overweight and obesity in urban area of Bangladesh. Annals of Global Health 2017;83(1):176.

63. Williams, P.T., Wood, P.D.. The effects of changing exercise levels on weight and age-related weight gain. International journal of obesity 2006;30(3):543-551.

64. Dong, C., Sanchez, L., Price, R.. Relationship of obesity to depression: a family-based study. International journal of obesity 2004;28(6):790-795.

65. Mroczek, D.K., Almeida, D.M.. The effect of daily stress, personality, and age on daily negative affect. Journal of personality 2004;72(2):355-378.

66. Roberts, C., Troop, N., Connan, F., Treasure, J., Campbell, I.C.. The effects of stress on body weight: biological and psychological predictors of change in bmi. Obesity 2007;15(12):3045-3055.

67. Mummery, W.K., Schofield, G.M., Steele, R., Eakin, E.G., Brown, W.J.. Occupational sitting time and overweight and obesity in Australian workers. American journal of preventive medicine 2005;29(2):91-97.

68. Adachi-Mejia, A.M., Schifferdecker, K.E.. A mixed-methods approach to assessing barriers to physical activity among women with class i, class ii, and class iii obesity. Public health 2016;139:212-215. 
69. Jayawardena, R., Ranasinghe, P., Wijayabandara, M., Hills, A.P., Misra, A.. Nutrition transition and obesity among teenagers and young adults in south Asia. Curr Diabetes Rev 2016;.

70. Biswas, T., Islam, A., Islam, M.S., Pervin, S., Rawal, L.. Overweight and obesity among children and adolescents in Bangladesh: a systematic review and meta-analysis. public health 2017;142:94-101.

71. Das, J., Das, S.K., Ahmed, S., Chisti, M.J., Sarker, M.H.R., Farzana, F.D., Ferdous, F., Malek, M.A., Rahman, A., Faruque, A.S.G., et al. Association of television watching practices of mothers on overweight and obesity of their under-5 offspring in urban Bangladesh. Food and Nutrition Sciences 2014;5(19):1811.

72. Saquib, J., Saquib, N., Stefanick, M.L., Khanam, M.A., Anand, S., Rahman, M., Chertow, G.M., Barry, M., Ahmed, T., Cullen, M.R.. Sex differences in obesity, dietary habits, and physical activity among urban middle-class Bangladeshis. International journal of health sciences 2016;10(3):363.

73. Morgan, K., Sonnino, R.. The urban foodscape: world cities and the new food equation. Cambridge Journal of Regions, Economy and Society 2010;:rsq007.

74. Hoque, M.E., Long, K.Z., Niessen, L.W., Mamun, A.A.. Rapid shift toward overweight from double burden of underweight and overweight among Bangladeshi women: a systematic review and pooled analysis. Nutrition reviews 2015;73(7):438-447.

75. Lee, S., Cho, E., Grodstein, F., Kawachi, I., Hu, F.B., Colditz, G.A.. Effects of marital transitions on changes in dietary and other health behaviours in us women. International Journal of Epidemiology 2005;34(1):69-78.

76. Schoenborn, C.A.. Marital status and health, united states 1999-2002. 2004.

77. Robinson, J.A., Burke, A.E.. Obesity and hormonal contraceptive efficacy. Women's health 2013;9(5):453-466.

\section{Figure legends}

Figure 1: The odds and C.I. from binary regression fitted for BMI with the covariates, captioned in each figure Figure 2: The odds and C.I. from binary regression fitted for BMI with the covariates, captioned in each figure 


\section{Tables}

Table 1: List of variables in three categories

\begin{tabular}{|l|l|l|}
\hline Category I & Category II & Category III \\
\hline Age & Residence & Marital status \\
Highest educational level & Wealth Index & Total children ever born \\
Husband/partner's age & Respondent's working status & Age at 1st birth \\
Husband/partner's education & & Contraceptive method type \\
\hline
\end{tabular}


Table 2: Bivariate analysis of the variables in category I

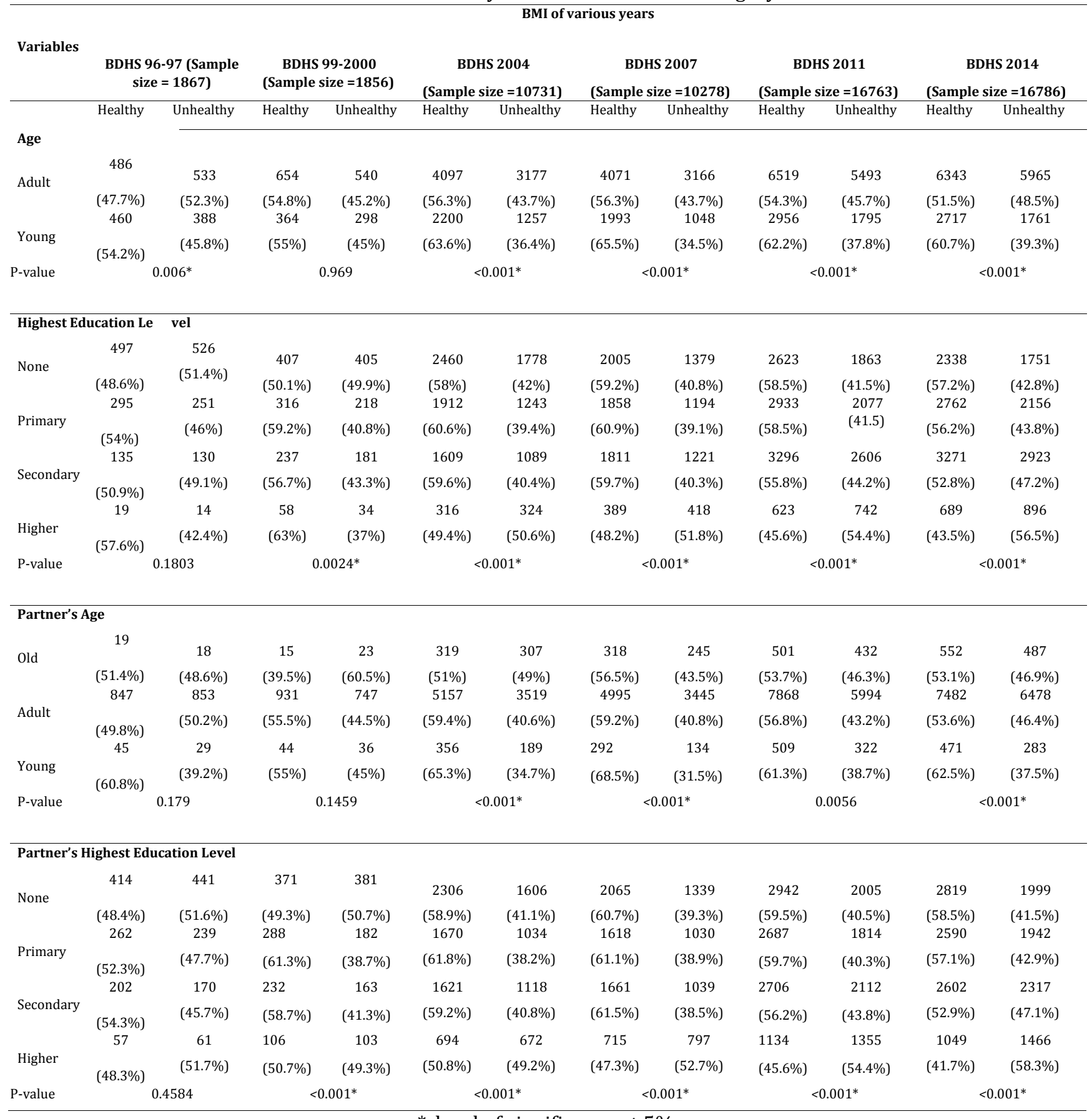

* level of significance at 5\% 
Table 3: Bivariate analysis of the variables in category II

\begin{tabular}{|c|c|c|c|c|c|c|c|c|c|c|c|c|}
\hline \multirow{4}{*}{$\begin{array}{l}\text { Variables } \\
\text { Residence }\end{array}$} & \multicolumn{12}{|c|}{ BMI of various years } \\
\hline & \multicolumn{2}{|c|}{$\begin{array}{c}\text { BDHS 96-97 (Sample } \\
\text { size = 1867) }\end{array}$} & \multicolumn{2}{|c|}{$\begin{array}{c}\text { BDHS 99-2000 } \\
\text { (Sample size }=1856 \text { ) }\end{array}$} & \multicolumn{2}{|c|}{$\begin{array}{c}\text { BDHS } 2004 \\
(\text { Sample size }=10731)\end{array}$} & \multicolumn{2}{|c|}{$\begin{array}{c}\text { BDHS } 2007 \\
\text { (Sample size }=10278)\end{array}$} & \multicolumn{2}{|c|}{$\begin{array}{c}\text { BDHS } 2011 \\
\text { (Sample size }=16763 \text { ) }\end{array}$} & \multicolumn{2}{|c|}{$\begin{array}{c}\text { BDHS } 2014 \\
\text { (Sample size }=16786 \text { ) }\end{array}$} \\
\hline & Healthy & Unhealthy & Healthy & Unhealthy & Healthy & Unhealthy & Healthy & Unhealthy & Healthy & Unhealthy & Healthy & Unhealthy \\
\hline & & & & & & & & & & & & \\
\hline Urban & $\begin{array}{c}102 \\
(49.5 \%) \\
844\end{array}$ & $\begin{array}{c}104 \\
(50.5 \%) \\
817\end{array}$ & $\begin{array}{c}259 \\
(56.2 \%) \\
759\end{array}$ & $\begin{array}{c}202 \\
(43.8 \%) \\
636\end{array}$ & $\begin{array}{c}2010 \\
(54.7 \%) \\
4287\end{array}$ & $\begin{array}{c}1666 \\
(45.3 \%) \\
2768\end{array}$ & $\begin{array}{c}2135 \\
(54.6 \%) \\
3929\end{array}$ & $\begin{array}{c}1775 \\
(45.4 \%) \\
2439\end{array}$ & $\begin{array}{c}2971 \\
(50.6 \%) \\
6504\end{array}$ & $\begin{array}{c}2901 \\
(49.4 \%) \\
4387\end{array}$ & $\begin{array}{c}2697 \\
(46.3 \%) \\
6363\end{array}$ & $\begin{array}{c}3134 \\
(53.7 \%) \\
4592\end{array}$ \\
\hline Rural & $(50.8 \%)$ & $(49.2 \%)$ & $(54.4 \%)$ & $(45.6 \%)$ & $(60.8 \%)$ & $(39.2 \%)$ & $(61.7 \%)$ & $(38.3 \%)$ & $(59.7 \%)$ & $(40.3 \%)$ & $(58.1 \%)$ & $(41.9 \%)$ \\
\hline P-value & \multicolumn{2}{|c|}{0.7813} & \multicolumn{2}{|c|}{0.5422} & \multicolumn{2}{|c|}{$<0.001^{*}$} & \multicolumn{2}{|c|}{$<0.001^{*}$} & \multicolumn{2}{|c|}{$<0.001^{*}$} & \multicolumn{2}{|c|}{$<0.001^{*}$} \\
\hline \multicolumn{13}{|l|}{ Wealth Index } \\
\hline Poorest & $\begin{array}{c}153 \\
(39.5 \%) \\
204\end{array}$ & $\begin{array}{c}234 \\
(60.5 \%) \\
211\end{array}$ & $\begin{array}{c}224 \\
(48.4 \%) \\
174\end{array}$ & $\begin{array}{c}239 \\
(51.6 \%) \\
170\end{array}$ & $\begin{array}{c}1077 \\
(55.8 \%) \\
1186\end{array}$ & $\begin{array}{c}853 \\
(44.2 \%) \\
746\end{array}$ & $\begin{array}{c}989 \\
(59.7 \%) \\
1189\end{array}$ & $\begin{array}{c}669 \\
(40.3 \%) \\
662\end{array}$ & $\begin{array}{c}1692 \\
(58.6 \%) \\
1969\end{array}$ & $\begin{array}{c}1195 \\
(41.4 \%) \\
1129\end{array}$ & $\begin{array}{c}1822 \\
(60.3 \%) \\
1937\end{array}$ & $\begin{array}{c}1201 \\
(39.7 \%) \\
1203\end{array}$ \\
\hline Poorer & $(49.2 \%)$ & $(50.8 \%)$ & $(50.6 \%)$ & $(49.4 \%)$ & $(61.4 \%)$ & $(38.6 \%)$ & $(64.2 \%)$ & $(35.8 \%)$ & $(63.6 \%)$ & $(36.4 \%)$ & $(61.7 \%)$ & $(38.3 \%)$ \\
\hline Middle & $\begin{array}{c}215 \\
(53.6 \%)\end{array}$ & $\begin{array}{c}186 \\
(46.4 \%)\end{array}$ & $\begin{array}{c}232 \\
(61.1 \%)\end{array}$ & $\begin{array}{c}148 \\
(38.9 \%)\end{array}$ & $\begin{array}{c}1245 \\
(62.1 \%)\end{array}$ & $\begin{array}{c}759 \\
(37.9 \%)\end{array}$ & $\begin{array}{c}1246 \\
(64.4 \%)\end{array}$ & $\begin{array}{c}688 \\
(35.6 \%)\end{array}$ & $\begin{array}{c}2000 \\
(62.1 \%)\end{array}$ & $\begin{array}{c}1221 \\
(37.9 \%)\end{array}$ & $\begin{array}{c}2005 \\
(58.8 \%)\end{array}$ & $\begin{array}{c}1405 \\
(41.2 \%)\end{array}$ \\
\hline Richer & $\begin{array}{c}206 \\
(57.5 \%)\end{array}$ & $\begin{array}{c}152 \\
(42.5 \%)\end{array}$ & $\begin{array}{c}181 \\
(60.1 \%)\end{array}$ & $\begin{array}{c}120 \\
(39.9 \%)\end{array}$ & $\begin{array}{c}1325 \\
(62 \%)\end{array}$ & $\begin{array}{c}813 \\
(38 \%)\end{array}$ & $\begin{array}{c}1281 \\
(61.9 \%)\end{array}$ & $\begin{array}{c}790 \\
(38.1 \%)\end{array}$ & $\begin{array}{c}2021 \\
(56.6 \%)\end{array}$ & $\begin{array}{c}1549 \\
(43.4 \%)\end{array}$ & $\begin{array}{c}1901 \\
(53.4 \%)\end{array}$ & $\begin{array}{c}1658 \\
(46.6 \%)\end{array}$ \\
\hline Richest & $\begin{array}{c}168 \\
(54.9 \%)\end{array}$ & $\begin{array}{c}138 \\
(45.1 \%)\end{array}$ & $\begin{array}{c}207 \\
(56.2 \%)\end{array}$ & $\begin{array}{c}161 \\
(43.8 \%)\end{array}$ & $\begin{array}{c}1464 \\
(53.7 \%)\end{array}$ & $\begin{array}{c}1263 \\
(46.3 \%)\end{array}$ & $\begin{array}{c}1359 \\
(49.2 \%)\end{array}$ & $\begin{array}{c}1405 \\
(50.8 \%)\end{array}$ & $\begin{array}{c}1793 \\
(45 \%)\end{array}$ & $\begin{array}{c}2194 \\
(55 \%)\end{array}$ & $\begin{array}{c}1395 \\
(38.2 \%)\end{array}$ & $\begin{array}{c}229 \\
(61.8 \%)\end{array}$ \\
\hline P-value & \multicolumn{2}{|c|}{$<0.001 *$} & \multicolumn{2}{|c|}{$<0.001^{*}$} & \multicolumn{2}{|c|}{$<0.001^{*}$} & \multicolumn{2}{|c|}{$<0.001^{*}$} & \multicolumn{2}{|c|}{$<0.001^{*}$} & \multicolumn{2}{|c|}{$<0.001^{*}$} \\
\hline \multicolumn{13}{|c|}{ Respondent' s Working Status } \\
\hline Unemployed & $\begin{array}{c}644 \\
(51.9 \%)\end{array}$ & $\begin{array}{c}598 \\
(48.1 \%)\end{array}$ & $\begin{array}{c}828 \\
(54.9 \%)\end{array}$ & $\begin{array}{c}679 \\
(45.1 \%)\end{array}$ & $\begin{array}{c}4855 \\
(58.5 \%)\end{array}$ & $\begin{array}{c}3447 \\
(41.5 \%)\end{array}$ & $\begin{array}{c}4140 \\
(57.7 \%)\end{array}$ & $\begin{array}{c}3038 \\
(42.3 \%)\end{array}$ & $\begin{array}{c}8200 \\
(56.7 \%)\end{array}$ & $\begin{array}{c}6267 \\
(43.3 \%)\end{array}$ & $\begin{array}{c}5962 \\
(52.6 \%)\end{array}$ & $\begin{array}{c}5376 \\
(47.4 \%)\end{array}$ \\
\hline Employed & $\begin{array}{c}302 \\
(48.4 \%)\end{array}$ & $\begin{array}{c}322 \\
(51.6 \%)\end{array}$ & $\begin{array}{c}190 \\
(54.6 \%)\end{array}$ & $\begin{array}{c}158 \\
(45.4 \%)\end{array}$ & $\begin{array}{c}1442 \\
(59.4 \%)\end{array}$ & $\begin{array}{c}986 \\
(40.6)\end{array}$ & $\begin{array}{c}1921 \\
(62 \%)\end{array}$ & $\begin{array}{c}1175 \\
(38 \%)\end{array}$ & $\begin{array}{c}1275 \\
(55.5 \%)\end{array}$ & $\begin{array}{c}1021 \\
(44.5 \%)\end{array}$ & $\begin{array}{c}3095 \\
(56.9 \%)\end{array}$ & $\begin{array}{c}2348 \\
(43.1 \%)\end{array}$ \\
\hline P-value & \multicolumn{2}{|c|}{0.222} & \multicolumn{2}{|c|}{0.5409} & \multicolumn{2}{|c|}{0.3565} & \multicolumn{2}{|c|}{$<0.001^{*}$} & \multicolumn{2}{|c|}{0.3128} & \multicolumn{2}{|c|}{$<0.001^{*}$} \\
\hline
\end{tabular}

* level of significance at $5 \%$ 
Table 4: Bivariate analysis of the variables in category III BMI of various years

\begin{tabular}{|c|c|c|c|c|c|c|c|c|c|c|c|c|}
\hline \multirow{2}{*}{ Variables } & \multicolumn{2}{|c|}{$\begin{array}{c}\text { BDHS 96-97 } \\
(\text { Sample size }=1867)\end{array}$} & \multicolumn{2}{|c|}{$\begin{array}{c}\text { BDHS 99-2000 } \\
\text { (Sample size }=\mathbf{1 8 5 6} \text { ) }\end{array}$} & \multicolumn{2}{|c|}{$\begin{array}{c}\text { BDHS } 2004 \\
\text { (Sample size }=10731 \text { ) }\end{array}$} & \multicolumn{2}{|c|}{$\begin{array}{c}\text { BDHS } 2007 \\
\text { (Sample size }=10278 \text { ) }\end{array}$} & \multicolumn{2}{|c|}{$\begin{array}{c}\text { BDHS } 2011 \\
\text { (Sample size }=16763 \text { ) }\end{array}$} & \multicolumn{2}{|c|}{$\begin{array}{c}\text { BDHS } 2014 \\
\text { (Sample size }=16786 \text { ) }\end{array}$} \\
\hline & Healthy & Unhealthy & Healthy & Unhealthy & Healthy & Unhealthy & Healthy & Unhealthy & Healthy & Unhealthy & Healthy & Unhealthy \\
\hline \multicolumn{13}{|c|}{ Marital Status } \\
\hline Married & $\begin{array}{c}911 \\
(50.3 \%)\end{array}$ & $\begin{array}{c}900 \\
(49.7 \%)\end{array}$ & $\begin{array}{c}990 \\
(55.1 \%)\end{array}$ & $\begin{array}{c}806 \\
(44.9 \%)\end{array}$ & $\begin{array}{c}5832 \\
(59.2 \%)\end{array}$ & $\begin{array}{c}4015 \\
(40.8 \%)\end{array}$ & $\begin{array}{c}5605 \\
(59.4 \%)\end{array}$ & $\begin{array}{c}3824 \\
(40.6 \%)\end{array}$ & $\begin{array}{c}8878 \\
(56.8 \%)\end{array}$ & $\begin{array}{c}6748 \\
(43.2 \%)\end{array}$ & $\begin{array}{c}8505 \\
(54 \%)\end{array}$ & $\begin{array}{c}7248 \\
(46 \%)\end{array}$ \\
\hline Widowed & $\begin{array}{c}12 \\
(52.2 \%)\end{array}$ & $\begin{array}{c}11 \\
(47.8 \%)\end{array}$ & $\begin{array}{c}11 \\
(57.9 \%)\end{array}$ & $\begin{array}{c}8 \\
(42.1 \%)\end{array}$ & $\begin{array}{c}248 \\
(50.2 \%)\end{array}$ & $\begin{array}{c}246 \\
(49.8 \%)\end{array}$ & $\begin{array}{c}236 \\
(50.6 \%)\end{array}$ & $\begin{array}{c}230 \\
(49.4 \%)\end{array}$ & $\begin{array}{c}323 \\
(50.2 \%)\end{array}$ & $\begin{array}{c}321 \\
(49.8 \%)\end{array}$ & $\begin{array}{c}314 \\
(50.4 \%)\end{array}$ & $\begin{array}{c}309 \\
(49.6 \%)\end{array}$ \\
\hline Divorced & $\begin{array}{c}23 \\
(69.7 \%)\end{array}$ & $\begin{array}{c}10 \\
(30.3 \%)\end{array}$ & $\begin{array}{c}3 \\
(42.9 \%)\end{array}$ & $\begin{array}{c}4 \\
(57.1 \%)\end{array}$ & $\begin{array}{c}85 \\
(54.8 \%)\end{array}$ & $\begin{array}{c}70 \\
(45.2 \%)\end{array}$ & $\begin{array}{c}84 \\
(60.4 \%)\end{array}$ & $\begin{array}{c}55 \\
(39.6 \%)\end{array}$ & $\begin{array}{c}115 \\
(53.5 \%)\end{array}$ & $\begin{array}{c}100 \\
(46.5 \%)\end{array}$ & $\begin{array}{c}104 \\
(61.2 \%)\end{array}$ & $\begin{array}{c}66 \\
(38.8 \%)\end{array}$ \\
\hline $\begin{array}{l}\text { Not living } \\
\text { together }\end{array}$ & NA & NA & $\begin{array}{c}14 \\
(41.2 \%)\end{array}$ & $\begin{array}{c}20 \\
(58.8 \%)\end{array}$ & $\begin{array}{c}132 \\
(56.2 \%)\end{array}$ & $\begin{array}{c}103 \\
(43.8 \%)\end{array}$ & $\begin{array}{c}139 \\
(57 \%)\end{array}$ & $\begin{array}{c}105 \\
(43 \%)\end{array}$ & $\begin{array}{c}159 \\
(57.2 \%)\end{array}$ & $\begin{array}{c}119 \\
(42.8 \%)\end{array}$ & $\begin{array}{c}137 \\
(57.1 \%)\end{array}$ & $\begin{array}{c}103 \\
(42.9 \%)\end{array}$ \\
\hline P-value & & 864 & & 767 & & $0006^{*}$ & & $020^{*}$ & & $072 *$ & & 529 \\
\hline
\end{tabular}

Total Child ren Ever Born

\begin{tabular}{|c|c|c|c|c|c|c|c|c|c|c|c|c|}
\hline None & NA & NA & NA & NA & $\begin{array}{c}688 \\
(66 \%)\end{array}$ & $\begin{array}{c}355 \\
(34 \%)\end{array}$ & $\begin{array}{c}521 \\
(60.1 \%)\end{array}$ & $\begin{array}{c}346 \\
(39.9 \%)\end{array}$ & $\begin{array}{c}523 \\
(58.4 \%)\end{array}$ & $\begin{array}{c}373 \\
(41.6 \%)\end{array}$ & $\begin{array}{c}783 \\
(59.1 \%)\end{array}$ & $\begin{array}{c}541 \\
(40.9 \%)\end{array}$ \\
\hline 1 & $\begin{array}{c}239 \\
(51.8 \%)\end{array}$ & $\begin{array}{c}222 \\
(48.2 \%)\end{array}$ & $\begin{array}{c}279 \\
(55.2 \%)\end{array}$ & $\begin{array}{c}226 \\
(44.8 \%)\end{array}$ & $\begin{array}{c}1131 \\
(60.5 \%)\end{array}$ & $\begin{array}{c}737 \\
(39.5 \%)\end{array}$ & $\begin{array}{c}1199 \\
(60.6 \%)\end{array}$ & $\begin{array}{c}779 \\
(39.4 \%)\end{array}$ & $\begin{array}{c}1261 \\
(58.7 \%)\end{array}$ & $\begin{array}{c}889 \\
(41.3 \%)\end{array}$ & $\begin{array}{c}2008 \\
(54.9 \%)\end{array}$ & $\begin{array}{c}1651 \\
(45.1 \%)\end{array}$ \\
\hline $2-3$ & $\begin{array}{c}403 \\
(55.9 \%)\end{array}$ & $\begin{array}{c}318 \\
(44.1 \%)\end{array}$ & $\begin{array}{c}452 \\
(57.1 \%)\end{array}$ & $\begin{array}{c}339 \\
(42.9 \%)\end{array}$ & $\begin{array}{l}2425 \\
(59.6 \%)\end{array}$ & $\begin{array}{c}1644 \\
(40.4 \%)\end{array}$ & $\begin{array}{c}2461 \\
(59.5 \%)\end{array}$ & $\begin{array}{c}1673 \\
(40.5 \%)\end{array}$ & $\begin{array}{c}2547 \\
(54.7 \%)\end{array}$ & $\begin{array}{c}2109 \\
(45.3 \%)\end{array}$ & $\begin{array}{c}4083 \\
(52.4 \%)\end{array}$ & $\begin{array}{c}3714 \\
(47.6 \%)\end{array}$ \\
\hline $4+$ & $\begin{array}{c}304 \\
(44.4 \%)\end{array}$ & $\begin{array}{c}381 \\
(55.6 \%)\end{array}$ & $\begin{array}{c}287 \\
(51.3 \%)\end{array}$ & $\begin{array}{c}273 \\
(48.7 \%)\end{array}$ & $\begin{array}{c}2053 \\
(54.7 \%)\end{array}$ & $\begin{array}{c}1698 \\
(45.3 \%)\end{array}$ & $\begin{array}{c}1883 \\
(57.1 \%)\end{array}$ & $\begin{array}{c}1416 \\
(42.9 \%)\end{array}$ & $\begin{array}{c}1491 \\
(56.1 \%)\end{array}$ & $\begin{array}{c}1165 \\
(43.9 \%)\end{array}$ & $\begin{array}{c}2186 \\
(54.6 \%)\end{array}$ & $\begin{array}{c}1820 \\
(45.4 \%)\end{array}$ \\
\hline P-value & & $01^{*}$ & & 98 & & $1^{*}$ & & 442 & & $107^{*}$ & & $01^{*}$ \\
\hline
\end{tabular}

\begin{tabular}{|c|c|c|c|c|c|c|c|c|c|c|c|c|}
\hline Age at Firs & : Birth & & & & & & & & & & & \\
\hline$<20$ years & $\begin{array}{c}826 \\
(50.3 \%)\end{array}$ & $\begin{array}{c}815 \\
(49.7 \%)\end{array}$ & $\begin{array}{c}853 \\
(55.1 \%)\end{array}$ & $\begin{array}{c}694 \\
(44.9 \%)\end{array}$ & $\begin{array}{c}4885 \\
(58.5 \%)\end{array}$ & $\begin{array}{c}3472 \\
(41.5 \%)\end{array}$ & $\begin{array}{c}4649 \\
(59.7 \%)\end{array}$ & $\begin{array}{c}3135 \\
(40.3 \%)\end{array}$ & $\begin{array}{c}7302 \\
(57.6 \%)\end{array}$ & $\begin{array}{c}5366 \\
(42.4 \%)\end{array}$ & $\begin{array}{c}6995 \\
(54.6 \%)\end{array}$ & $\begin{array}{c}5813 \\
(45.4 \%)\end{array}$ \\
\hline 20-30 years & $\begin{array}{c}119 \\
(53.1 \%)\end{array}$ & $\begin{array}{c}105 \\
(46.9 \%)\end{array}$ & $\begin{array}{c}162 \\
(53.3 \%)\end{array}$ & $\begin{array}{c}142 \\
(46.7 \%)\end{array}$ & $\begin{array}{c}703 \\
(54.6 \%)\end{array}$ & $\begin{array}{c}585 \\
(45.4 \%)\end{array}$ & $\begin{array}{c}877 \\
(55.6 \%)\end{array}$ & $\begin{array}{c}699 \\
(44.4 \%)\end{array}$ & $\begin{array}{c}1315 \\
(50.5 \%)\end{array}$ & $\begin{array}{c}1287 \\
(49.5 \%)\end{array}$ & $\begin{array}{c}1238 \\
(48.2 \%)\end{array}$ & $\begin{array}{c}1328 \\
(51.8 \%)\end{array}$ \\
\hline $30-40$ years & $\begin{array}{c}1 \\
(50 \%)\end{array}$ & $\begin{array}{c}1 \\
(50 \%)\end{array}$ & $\begin{array}{c}3 \\
(60 \%)\end{array}$ & $\begin{array}{c}2 \\
(40 \%)\end{array}$ & $\begin{array}{c}21 \\
(50 \%)\end{array}$ & $\begin{array}{c}21 \\
(50 \%)\end{array}$ & $\begin{array}{c}17 \\
(34 \%)\end{array}$ & $\begin{array}{c}33 \\
(66 \%)\end{array}$ & $\begin{array}{c}44 \\
(47.3 \%)\end{array}$ & $\begin{array}{c}49 \\
(52.7 \%)\end{array}$ & $\begin{array}{c}43 \\
(50 \%)\end{array}$ & $\begin{array}{c}43 \\
(50 \%)\end{array}$ \\
\hline Over 40 & $\mathrm{NA}$ & NA & NA & NA & $\begin{array}{c}0 \\
(0 \%)\end{array}$ & $\begin{array}{c}1 \\
(100 \%)\end{array}$ & $\begin{array}{c}0 \\
(0 \%)\end{array}$ & $\begin{array}{c}1 \\
(100 \%)\end{array}$ & $\mathrm{NA}$ & $\mathrm{NA}$ & $\begin{array}{c}1 \\
(50 \%)\end{array}$ & $\begin{array}{c}1 \\
(50 \%)\end{array}$ \\
\hline P-value & \multicolumn{2}{|c|}{$0.7356^{\alpha}$} & \multicolumn{2}{|c|}{$0.8168^{\alpha}$} & \multicolumn{2}{|c|}{$0.0253^{\alpha}$} & \multicolumn{2}{|c|}{$<0.001^{* \alpha}$} & \multicolumn{2}{|c|}{$<0.001^{*}$} & \multicolumn{2}{|c|}{$<0.001^{* \alpha}$} \\
\hline Contracepti & ve Meth & Type & & & & & & & & & & \\
\hline None used & $\begin{array}{c}523 \\
(51.1 \%)\end{array}$ & $\begin{array}{c}501 \\
(84.9 \%)\end{array}$ & $\begin{array}{c}438 \\
(51 \%)\end{array}$ & $\begin{array}{c}420 \\
(49 \%)\end{array}$ & $\begin{array}{c}2570 \\
(56.2 \%)\end{array}$ & $\begin{array}{c}2004 \\
(43.8 \%)\end{array}$ & $\begin{array}{c}2639 \\
(56.8 \%)\end{array}$ & $\begin{array}{c}2011 \\
(43.2 \%)\end{array}$ & $\begin{array}{c}3525 \\
(54.4 \%)\end{array}$ & $\begin{array}{c}2959 \\
(45.6 \%)\end{array}$ & $\begin{array}{c}3285 \\
(52 \%)\end{array}$ & $\begin{array}{c}3029 \\
(48 \%)\end{array}$ \\
\hline Folkloric & $\begin{array}{c}6 \\
(35.3 \%)\end{array}$ & $\begin{array}{c}11 \\
(64.7 \%)\end{array}$ & $\begin{array}{c}4 \\
(36.4 \%)\end{array}$ & $\begin{array}{c}7 \\
(63.6 \%)\end{array}$ & $\begin{array}{l}37 \\
(56.1 \%)\end{array}$ & $\begin{array}{c}29 \\
(43.9 \%)\end{array}$ & $\begin{array}{c}27 \\
(54 \%)\end{array}$ & $\begin{array}{c}23 \\
(46 \%)\end{array}$ & $\begin{array}{l}39 \\
(60.9 \%)\end{array}$ & $\begin{array}{c}25 \\
(39.1 \%)\end{array}$ & $\begin{array}{c}13 \\
(46.4 \%)\end{array}$ & $\begin{array}{c}15 \\
(53.6 \%)\end{array}$ \\
\hline Traditional & $\begin{array}{c}57 \\
(47.9 \%)\end{array}$ & $\begin{array}{c}62 \\
(52.1 \%)\end{array}$ & $\begin{array}{c}85 \\
(53.1 \%)\end{array}$ & $\begin{array}{c}75 \\
(46.9 \%)\end{array}$ & $\begin{array}{l}575 \\
(52.4 \%)\end{array}$ & $\begin{array}{c}522 \\
(47.6 \%)\end{array}$ & $\begin{array}{c}451 \\
(54.5 \%)\end{array}$ & $\begin{array}{c}376 \\
(45.5 \%)\end{array}$ & $\begin{array}{l}801 \\
(53.4 \%)\end{array}$ & $\begin{array}{c}698 \\
(46.6 \%)\end{array}$ & $\begin{array}{c}638 \\
(48.7 \%)\end{array}$ & $\begin{array}{c}672 \\
(51.3 \%)\end{array}$ \\
\hline Modern & $\begin{array}{c}360 \\
(50.9 \%)\end{array}$ & $\begin{array}{c}347 \\
(49.1 \%)\end{array}$ & $\begin{array}{c}491 \\
(59.4 \%)\end{array}$ & $\begin{array}{c}336 \\
(40.6 \%)\end{array}$ & $\begin{array}{l}3115 \\
(62.4 \%)\end{array}$ & $\begin{array}{c}1879 \\
(37.6 \%)\end{array}$ & $\begin{array}{c}2947 \\
(62 \%)\end{array}$ & $\begin{array}{c}1804 \\
(38 \%)\end{array}$ & $\begin{array}{l}5110 \\
(58.6 \%)\end{array}$ & $\begin{array}{c}3606 \\
(41.4 \%)\end{array}$ & $\begin{array}{c}5124 \\
(56.1 \%)\end{array}$ & $\begin{array}{c}4010 \\
(43.9 \%)\end{array}$ \\
\hline P-value & & 605 & & $036^{*}$ & & $01 *$ & & $01^{*}$ & & $01 *$ & & $01^{*}$ \\
\hline
\end{tabular}


* level of significance at $5 \%$,

$\alpha$ expected cell count is below 5 , which compromised the P-value in the particular scale 


(1)

(a) Age of respondents and modern contraceptive use

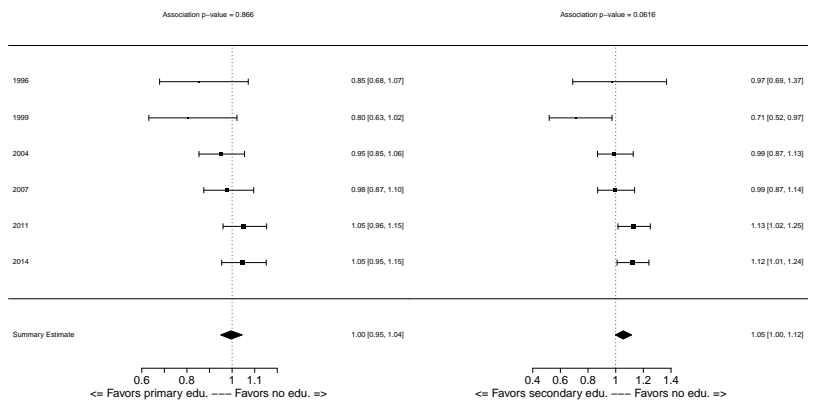

(c) Primary and secondary education of respondents

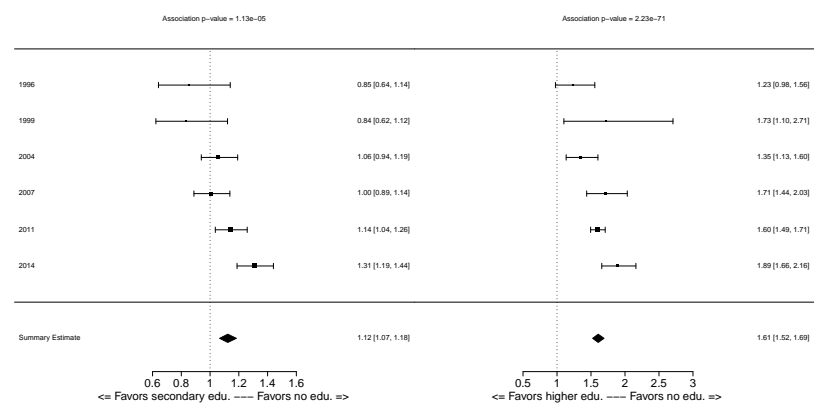

(e) Partner's secondary and higher education

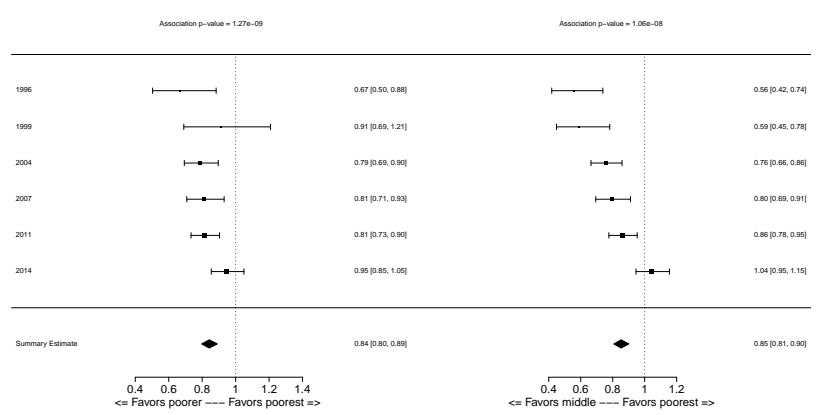

(g) Poorer and middle in wealth index

(1)

(b) Partner's age

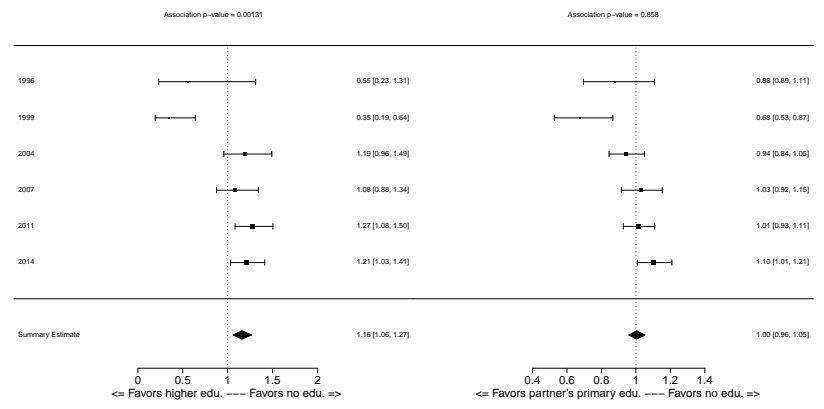

(d) Higher education of respondent and partner's primary education

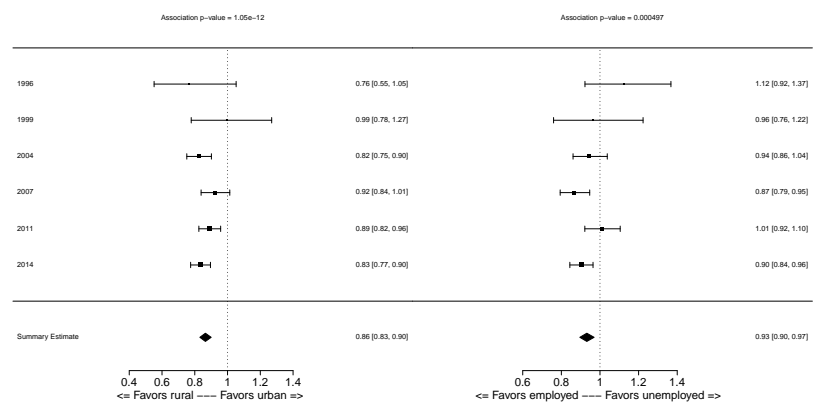

(f) Residence and working status

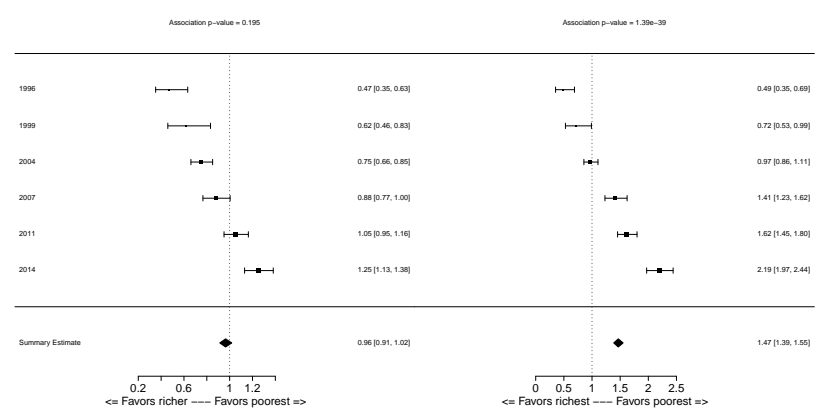

(h) Richer and richest in wealth index 


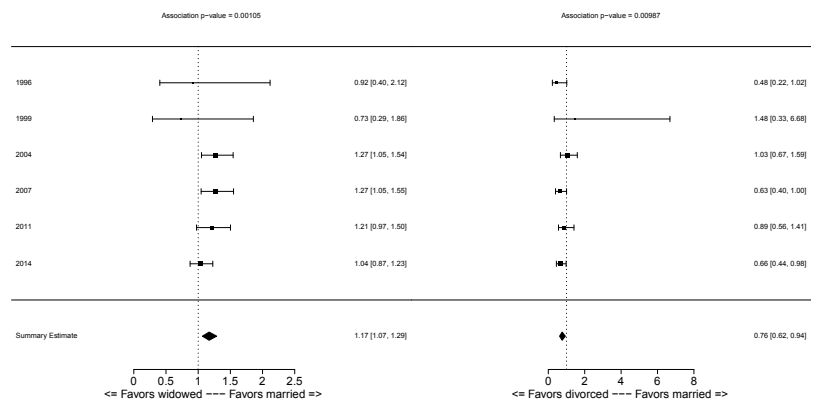

(a) Marital status

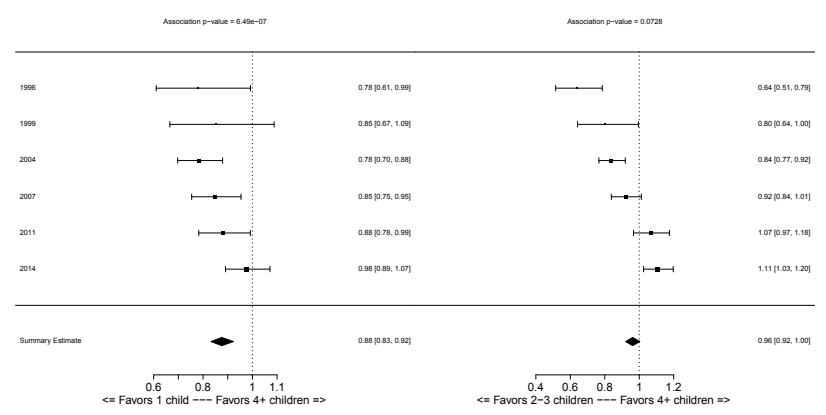

(c) Total children ever born

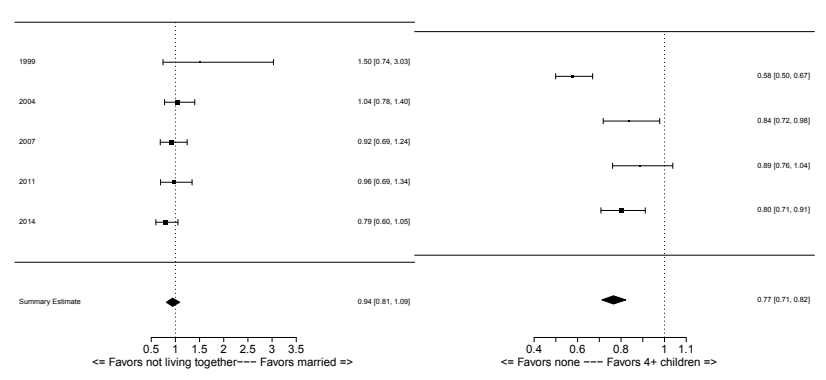

(b) Marital status and total children ever born

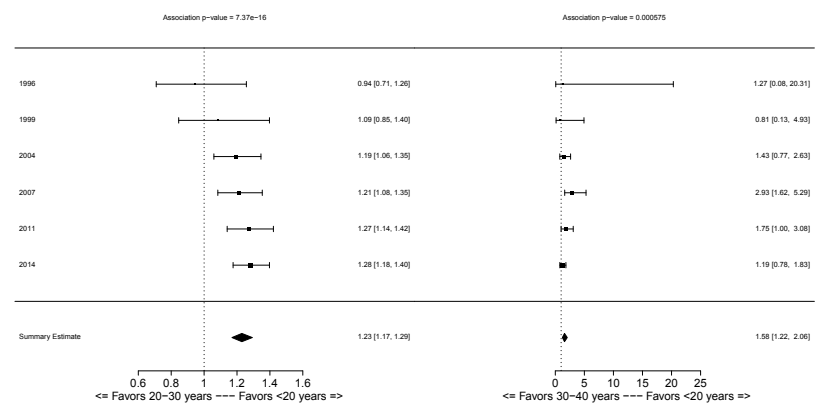

(d) Age at first birth

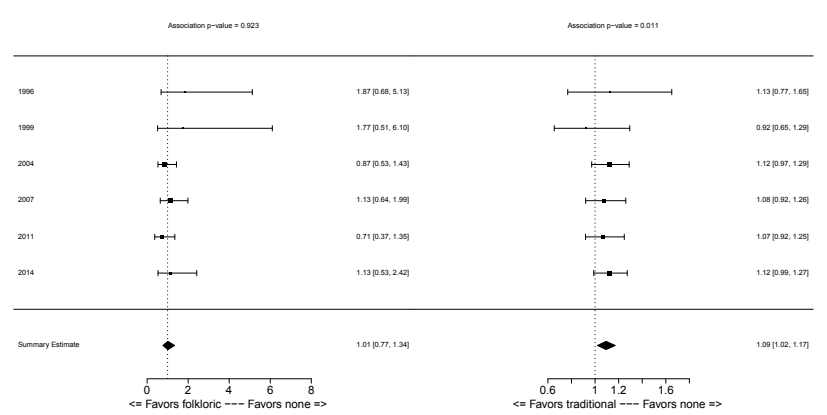

(e) Contraceptive method type 